\begin{tabular}{|c|c|}
\hline Title & Effect of biochar application on mineral and microbial properties of soils growing different plant species \\
\hline Author(s) & Hairani, A nna; Osaki, Mitsuru; W atanabe, Toshihiro \\
\hline Citation & $\begin{array}{l}\text { Soil science and plant nutrition, 62(5-6), 519-525 } \\
\text { https://doi.org/10.1080/00380768.2016.1212648 }\end{array}$ \\
\hline Issue Date & 2016-11 \\
\hline Doc URL & http:/hdl.handle.net/2115/67487 \\
\hline Rights & $\begin{array}{l}\text { This is an A ccepted Manuscript of an article published by Taylor \& Francis in Soil science and plant nutrition on } 2016 \\
\text { Nov, avail lable online: http:/www.tandfonline.com/http://dx.doi.org/10.1080/00380768.2016.1212648 }\end{array}$ \\
\hline Type & article (author version) \\
\hline File Information & July 2016.pdf \\
\hline
\end{tabular}

Instructions for use 


\section{Title of the paper}

2 Effect of biochar application on mineral and microbial properties of soils growing different

3 plant species

4

5 Names of the authors

6 - Hairani, Anna ${ }^{1}$

7 - Osaki, Mitsuru ${ }^{2}$

8 - Watanabe, Toshihiro ${ }^{2}$

9

Addresses of the institution

11 1. Graduate School of Agriculture, Hokkaido University, Kita 9 Nishi 9, Kita-ku, Sapporo 060-8589, Japan

2. Research Faculty of Agriculture, Hokkaido University, Kita 9 Nishi 9, Kita-ku, Sapporo 060-8589, Japan

\section{Contact information of corresponding author}

17 Name: Toshihiro Watanabe

18 Postal address: Research Faculty of Agriculture, Hokkaido University, Kita 9 Nishi 9,

19 Kita-ku, Sapporo 060-8589, Japan

20 Email: nabe@chem.agr.hokudai.ac.jp

21 Fax: +81-11-706-2498

22 Tel: +81-11-706-2498 
1 Type of contribution and division of the manuscript

2 Full-length paper, 7. Fertilizers and soil amendments

3

4 


\section{ABSTRACT}

2 Biochar is widely used as a soil amendment to increase crop yields. However, the details of

3 its impact on soil properties have not been fully understood. A pot experiment was

4 conducted using soybean and sorghum under four soil treatment combinations (cattle

5 farmyard manure with or without biochar and rapeseed cake with or without biochar) to

6 elucidate the mechanisms of its beneficial effects on plant growth in terms of the microbial

7 community structure and mineral availability in soils with different types of organic manure

8 application. The application of biochar significantly increased the growth of both species,

9 particularly sorghum with rapeseed cake application by 1.48 times higher than that without

10 biochar. Microbial activity in soil was also enhanced by biochar application in both species

11 with rapeseed cake application, particularly in sorghum. Principal component analysis

12 using Biolog EcoPlate ${ }^{\mathrm{TM}}$ data indicated that biochar application changed the microbial

13 community structure in soil, particularly sorghum grown soil. The changes in microbial

14 community structure in sorghum were considered to be at least partly affected by changes

15 in soil $\mathrm{pH}$ due to interaction between plant and biochar under organic manure application.

16 Biochar application had little effect on the profile of ammonium-acetate-extractable mineral

17 elements in soil including calcium, potassium, magnesium, sodium, and sulphur with both

18 types of manure application under soybean. Under sorghum, however, biochar with

19 rapeseed cake manure application altered the profile. This alteration is attributable to an

20 increase in the extractable concentration of certain metals in the soil including aluminum,

21 cadmium, and zinc, possibly caused by enhanced organic matter decomposition producing

22 metal-chelating organic compounds. These different changes in the soil properties by 
1 biochar application may be directly or indirectly related to the different growth responses of

2 different plant species to biochar application under organic manure application.

4 Keywords: microbial activity, mineral element, organic manure, sorghum, wood biochar

\section{1. Introduction}

7 Driven by population growth, increased human pressure on land has forced the conversion

8 of natural landscapes into agricultural fields while simultaneously depleting the land under

9 agricultural use (Lal 2009). Therefore, there is an urgent need to establish effective

10 agricultural management practices that not only increase food production but also prevent

11 the negative environmental impacts of intensive agriculture. There are various fertilizers

12 and soil amendments that are able to improve soil fertility and crop productivity. Fertilizers

13 are necessary to increase crop production, and are supplied mainly in the form of chemical

14 amendments. However, the continuous and excessive use of chemical fertilizers may result

15 in environmental pollution. In addition, agriculture largely depending on chemical

16 fertilizers is not sustainable in terms of a shortage of their resources and high energy costs

17 for their production (Ryan et al. 2012; Woods et al. 2010). Organic fertilizers may be

18 alternatively used as chemical fertilizers; such organic fertilizers can also act as soil

19 amendments which improve the physical, chemical, and biological properties of soil.

20 However, organic fertilizers are less effective than chemical fertilizers because nitrogen $(\mathrm{N})$

21 and phosphorus (P) mainly occur in organic forms in organic fertilizer. 
1 Biochar is a product of the thermal degradation of organic material under oxygen-limited

2 conditions. With respect to appearance, it is similar to charcoal produced by natural

3 burning; however, it is distinguished by its use as a soil amendment (Sohi et al. 2009;

4 Lehmann and Joseph 2009). Many studies have shown the beneficial effects of biochar on

5 soil chemical properties such as pH (Topoliantz et al. 2007; Masulili et al. 2010; Yuan et al.

6 2011), nutrient availability (Chan et al. 2008; Haefele et al. 2008), nutrient retention

7 (Glaser et al. 2002; Lehmann et al. 2003), and cation-exchange capacity (Glaser et al.

8 2002; Masulili et al. 2010; Yuan et al. 2011). Improvements in the growth and yield of

9 plants following biochar application have also been reported in various crop species,

10 including cowpea and rice (Lehmann et al. 2003), radish (Chan et al. 2008), soybean

11 (Tagoe et al. 2007), and maize (Yamato et al. 2006).

12 Recently, the use of organic fertilizers in soil to increase crop productivity has received

13 considerable attention. The incorporation of organic fertilizers is a useful approach for

14 maintaining organic matter content in soil and thereby enhance soil biological activity and

15 increase nutrient content, which, in turn, contributes to increasing crop productivity

16 (Dikinya and Mufwanzala 2010; Diacono and Montemurro 2010). However, in order to

17 supply available nutrients to plants, organic fertilizers need to be mineralized by soil

18 microorganisms. Biochars have been shown to have a positive effect on soil fertility and

19 plant growth (as described above); however, little information is available on their effects

20 when combined with manure, particularly in terms of the mineral and microbial properties

21 of soil. Therefore, this study assessed the effects of biochar on the microbial community 
1 structure and mineral availability in soils growing different crop species under different

2 organic manure treatments.

4 2. Materials and methods

\section{2.1. Experimental setup}

6 A pot experiment was conducted using soybean and sorghum under four soil treatment

7 combinations (cattle farmyard manure with/without biochar and rapeseed cake with/without

8 biochar) to examine the effects of wood biochar on the microbial community structure and

9 mineral availability in soils (Table 1). Soils (Gleyic Fluvisol) were collected from the 0-25

$10 \mathrm{~cm}$ layer at the experimental farm of Hokkaido University. The soil was air-dried and

11 passed through a $2.0 \mathrm{~mm}$ mesh screen. Then, $0.8 \mathrm{~L}$ of soil and $0.8 \mathrm{~L}$ of perlite were mixed

12 and placed in a plastic pot $(1.6 \mathrm{~L})$. Since soil used in a preliminary experiment showed a

13 compacted layer and little penetration of plant root, we mixed soil with perlite to improve

14 soil physical conditions. The biochar used in this experiment was purchased from

15 Shimokawa City Forest Organization Carbon Industry and was produced from broad-leaved

16 trees at $400^{\circ} \mathrm{C}$; the biochar had a Carbon (C) content of $71.8 \%$. The amount of fine biochar

$17(<0.25 \mathrm{~mm})$ applied to each pot was $28 \mathrm{~g}$ (equivalent to a field application rate of $35 \mathrm{t} \mathrm{ha}^{-1}$ ).

18 Two different types of organic fertilizer were used: cattle farmyard manure $(0.8 \% \mathrm{~N}, 1.7 \%$

$19 \mathrm{P}_{2} \mathrm{O}_{5}$, and $1.8 \% \mathrm{~K}_{2} \mathrm{O}$ ) and rapeseed cake (5.3\% N, 2.0\% $\mathrm{P}_{2} \mathrm{O}_{5}$, and $1.0 \% \mathrm{~K}_{2} \mathrm{O}$ ); $31.75 \mathrm{~g}$ of

20 cattle farmyard manure (providing $0.254 \mathrm{~g} \mathrm{~N}, 0.540 \mathrm{~g} \mathrm{P}_{2} \mathrm{O}_{5}$, and $0.572 \mathrm{~g} \mathrm{~K}_{2} \mathrm{O}$ ) or $4.793 \mathrm{~g}$ of

21 rapeseed cake (providing $0.254 \mathrm{~g} \mathrm{~N}, 0.096 \mathrm{~g} \mathrm{P}_{2} \mathrm{O}_{5}$, and $0.048 \mathrm{~g} \mathrm{~K}_{2} \mathrm{O}$ ) was applied to each

22 pot. In treatments with rapeseed cake, $0.878 \mathrm{~g}$ of calcium superphosphate and $0.381 \mathrm{~g}$ of 
$1 \mathrm{~K}_{2} \mathrm{SO}_{4}$ were added to make the application rates of each of $\mathrm{N}, \mathrm{P}_{2} \mathrm{O}_{5}$, and $\mathrm{K}_{2} \mathrm{O}$ equal to 100

$2 \mathrm{~kg} \mathrm{ha}^{-1}$. These organic fertilizers were used in the present study because they are very

3 common in crop cultivation but their chemical properties differ remarkably. Chemical

4 properties of biochar and each organic manure used in this study were shown in the

5 Supplementary material, Table S1. After mixing of the soil, perlite, fertilizer, and biochar,

6 the pots were incubated for 4 weeks in a greenhouse under moderately moist conditions

7 (40-60\% of field capacity depending on the soil condition).

8 Seeds of soybean (Glycine max (L.) Merr. cv. Toyoharuka) and sorghum (Sorghum bicolor

9 (L.) Moench cv. Hybrid Sorgo) were sterilized with 10\% (v/v) NaClO solution for 1 min

10 and then rinsed in deionized water. The seeds were sown and germinated in vermiculite.

11 After the first two leaves appeared (post 10-12 days), two of each species were

12 transplanted to each pot. Depending on the soil condition during the experiment, all pots

13 were then watered with deionized water to $40-60 \%$ of their field capacity. The pot

14 experiment was performed for 30 days (November 15-December 12, 2015) for soybean

15 and 40 days (November 15-December 23, 2015) for sorghum, according to their growth

16 rates in the vegetative stage. The experiment was conducted in a greenhouse at an almost

17 constant average temperature of $25^{\circ} \mathrm{C}$.

\section{2.2. Soil sampling and analysis}

19 Soil samples were collected at the time of plant sampling (30 and 40 days after sowing for 20 soybean and sorghum, respectively). After removing the plants (as described later), the soil

21 in each pot was mixed and remaining roots were removed. Fresh soil was taken for 
1 determining the microbial community structure and activity analyses using EcoPlate ${ }^{\mathrm{TM}}$

2 (Biolog Inc., CA, USA). The remaining soil was air-dried and sieved for chemical analysis.

3 EcoPlate contains three replicate wells of 31 of different carbon sources and water (no

4 substrate; tetrazolium dye only as a blank) for soil community analysis. For assessing

5 microbial carbon utilization patterns, a $1 \mathrm{~g}$ soil sample was thoroughly shaken by hand with

$610 \mathrm{ml}$ of sterile saline solution $(0.85 \% \mathrm{NaCl})$ and diluted 1000 times with the same saline

7 solution. A subsample of $150 \mu \mathrm{L}$ was inoculated directly into each well of the EcoPlate.

8 Three replicate suspensions were prepared for each soil sample. The EcoPlates were then

9 placed in an incubator at $25{ }^{\circ} \mathrm{C}$; purple color was formed when the microbes utilized the

10 carbon source and began to respire. The color development was measured every $24 \mathrm{~h}$ for $5-$

116 days using a microplate reader (Sunrise Remote, TECAN A-5082, Austria) at $595 \mathrm{~nm}$.

12 Changes in the pattern were compared and analyzed using principle components analysis

13 (PCA). The average well color development (AWCD) in each plate, which indicates

14 microbial activity, was calculated as follows:

$15 \quad \mathrm{AWCD}=\left[\Sigma\left(\mathrm{R}_{\mathrm{i}}-\mathrm{C}\right)\right] / 31$,

16 where $R_{i}$ and $C$ are the optical density (OD) values at $595 \mathrm{~nm}$ of the response wells

17 (containing sole carbon sources) and the control well (water), respectively. A high value of

18 AWCD reflects high microbial activity.

19 Soil $\mathrm{pH}\left(\mathrm{H}_{2} \mathrm{O}\right)$ was determined at a soil/water ratio of 1:2.5 using a $\mathrm{pH}$ meter (Mettler

20 Toledo, MP220, 2005). For determination of inorganic $\mathrm{N}\left(\mathrm{NH}_{4}-\mathrm{N}\right.$ and $\left.\mathrm{NO}_{3}-\mathrm{N}\right)$

21 concentration in the soils, $4 \mathrm{~g}$ samples were extracted with $40 \mathrm{~mL}$ of $2 \mathrm{M} \mathrm{KCl}$ by shaking

22 for $1 \mathrm{~h}$. The soil extracts were passed through filter paper (No. 6, Advantec, Tokyo, Japan). 
1 The $\mathrm{NH}_{4}-\mathrm{N}$ and $\mathrm{NO}_{3}-\mathrm{N}$ concentrations were determined by colorimetric methods.

2 Available P was extracted with Truog's solution and measured by spectrophotometry (U3 5100, HITACHI, Japan) at $710 \mathrm{~nm}$. Excluding inorganic $\mathrm{N}$ and available $\mathrm{P}$, the

4 concentrations of mineral elements in the soil were determined by extracting $2 \mathrm{~g}$ of soil

5 with $40 \mathrm{~mL}$ of $1 \mathrm{M}$ ammonium acetate, shaking for $30 \mathrm{~min}$, and passing through fine filter

6 paper (No. 5C, Advantec, Tokyo, Japan) to exclude fine soil particles. Thereafter, $5 \mathrm{~mL}$ of

7 the filtrate was digested with $2 \mathrm{~mL}$ of $61 \% \mathrm{HNO}_{3}$ as described later. The concentrations of

8 aluminum (Al), arsenic (As), boron (B), calcium (Ca), cadmium (Cd), cobalt (Co), cesium

9 (Cs), copper $(\mathrm{Cu})$, iron $(\mathrm{Fe})$, potassium $(\mathrm{K})$, lithium $(\mathrm{Li})$, magnesium $(\mathrm{Mg})$, manganese

10 (Mn), molybdenum (Mo), sodium ( $\mathrm{Na}$ ), nickel (Ni), rubidium (Rb), sulphur (S), selenium

11 (Se), strontium (Sr), vanadium (V), and zinc ( $\mathrm{Zn})$ in the digested solution were measured

12 using inductively coupled plasma mass spectrometry (ICP-MS) (ELAN, DRC-e, Perkin

13 Elmer, MA, USA).

\section{2.3. Plant sampling and analysis}

15 Plants were harvested at the end of the vegetative growth. Roots of the plants were washed

16 clean with tap water. The plants were then separated, washed with de-ionized water, and

17 dried in an oven at $70^{\circ} \mathrm{C}$ for 7 days, before being weighed and ground for mineral analysis.

18 The concentrations of mineral elements in the plant samples were determined as described

19 in Watanabe et al. (2015). Briefly, plant samples were digested in $2 \mathrm{~mL}$ of $61 \% \mathrm{HNO}_{3}$ (EL

20 grade, Kanto Chemical, Tokyo, Japan) at $110^{\circ} \mathrm{C}$ in a DigiPREP apparatus (SCP Science,

21 QC, Canada) for approximately $2 \mathrm{~h}$ until the solution had almost disappeared. After the

22 samples had cooled, $0.5 \mathrm{~mL} \mathrm{H}_{2} \mathrm{O}_{2} 30 \%$ (semiconductor grade, Santoku Chemical, Tokyo, 
1 Japan) was added, and the samples were heated at $110^{\circ} \mathrm{C}$ for a further 20 min. Once

2 digestion was complete, the tubes were cooled and made up to a volume of $10 \mathrm{~mL}$ by

3 adding $2 \% \mathrm{HNO}_{3}$. The concentrations of elements were measured using ICP-MS.

4 2.4. Data analysis

5 All experimental data were statistically analyzed using Minitab 16 (Minitab, Inc, United

6 States). Analysis of variance (ANOVA) followed by Tukey's test were used to detect

7 significant differences among treatments. To compare the results of the treatments with and

8 without biochar, paired Student's t-tests were applied. PCA was used to profile the

9 microbial communities and minerals in the soils.

\section{$11 \quad$ 3. Results}

\section{3.1. Growth and mineral accumulation of plants}

13 The total dry weight of both the plant species grown with rapeseed cake significantly 14 increased by the biochar application, particularly for sorghum (1.21 and 1.48 times higher 15 than that without biochar for soybean and sorghum, respectively) (Fig. 1). A similar trend 16 was also found for cattle farmyard manure; however, this was not statistically significant

17 (Fig. 1). The concentrations of some metal elements in leaf material are shown in Table 2.

18 Overall, irrespective of the plant species and manure type, the biochar application 19 decreased or did not affect the concentration of these elements.

\section{3.2. General chemical properties of soil}

21 Soil pH was higher in soil receiving cattle farmyard manure (Table 3). The biochar 22 application significantly increased soil $\mathrm{pH}$ under sorghum with each type of organic manure, 
1 but not in soybean. The concentration of inorganic $\mathrm{N}\left(\mathrm{NH}_{4}-\mathrm{N}\right.$ and $\left.\mathrm{NO}_{3}-\mathrm{N}\right)$ did not differ

2 significantly between the treatments (Table 3). Available P concentration was higher in

3 soils receiving cattle farmyard manure; however, no biochar effect was observed for either

4 plant grown soil (Table 3). The concentration of ammonium-acetate-extractable $\mathrm{S}$ in soil

5 increased under sorghum because of biochar application with rapeseed cake (Table 3).

\section{3.3. Microbial activity and community structure of soil}

7 The microbial activity in soil was estimated by AWCD. A high value of AWCD reflects

8 higher microbial activity. Figure 2 presents the AWCD values obtained from the EcoPlate.

9 For both soybean and sorghum grown soils with rapeseed cake, biochar application

10 significantly increased AWCD compared to the case without biochar. When PCA was

11 conducted to assess the utilization patterns of the different carbon sources, the total

12 variance explained by the first two components was $39 \%$ and $44 \%$ for soybean and

13 sorghum, respectively. In the soybean grown soil, the score plot of PCA showed a

14 separation between the B0M2 treatment and the other treatments in PC1 (Fig. 3).

15 Meanwhile, in the score plot of the sorghum grown soil, the soil with biochar application

16 shifted negatively along PC1 in both the cattle farmyard manure and rapeseed cake 17 treatments (Fig. 3).

\section{3.4. Mineral profile of soil}

19 PCA was also used to examine the treatment effects on the mineral profile of the soils.

20 Figure 4 shows the score plot of the first two components from the ammonium-acetate-

21 extractable concentrations of each mineral element in soils growing soybean or sorghum.

22 The first two components accounted for $67 \%$ and $92 \%$ of the total variance for the soybean 
1 and sorghum soils, respectively. In both species, a clear separation in the score plot was

2 observed between the different types of organic fertilizer applied to the soil (Fig 4).

3 Moreover, the biochar application altered the profile of the extractable mineral elements in

4 the sorghum grown soil with rapeseed cake (Fig. 4), whereas it did not affect that in the 5 soybean grown soil (Fig. 4).

7 4. Discussion

8 It has been reported that the positive effect of biochar on plant growth may be related to the

9 nutrient-retention capacity of biochar (Glaser et al. 2002) and its sorption capacity for toxic

10 metals and some phytotoxic compounds (Hille and den Ouden 2005; Lair et al. 2006). In

11 the present study, the biochar application significantly enhanced the growth of both the

12 plant species grown in soils with rapeseed cake, and the same trend was also observed in

13 their growth with cattle farmyard manure (Fig. 1), indicating that the combined application

14 of organic manure with biochar is effective at increasing crop yield. This growth promotion

15 effect was more remarkable in the soil with rapeseed cake for sorghum. Therefore, different

16 plant species as well as different types of organic manure may affect soil-biochar

17 interactions differently. This raises the question regarding the factors causing these

18 differences.

19 In both soybean and sorghum grown soils, AWCD-estimated microbial activity was

20 increased by biochar application with rapeseed cake (Fig. 2). It has been reported that

21 biochar provides a suitable habitat for microorganisms (Pietikainen et al. 2000) and

22 produces substances that stimulate the growth of microbes (Kasozi et al. 2010). Rapeseed 
1 cake may have suitable characteristics for the exertion of these positive effects of biochar

2 on microorganisms. The enhanced microbial activity can be expected to enhance the

3 mineralization of rapeseed cake applied to soils. However, significant differences were not

4 found for both plant species in inorganic $\mathrm{N}$ and available P concentrations between soils

5 with and without biochar in the rapeseed cake treatment. By contrast, a significant increase

6 was found in concentrations of extractable $\mathrm{S}$, including $\mathrm{SO}_{4}{ }^{2-}$ and soluble organic $\mathrm{S}$ such as

7 S-containing amino acids, because of biochar application under sorghum in the rapeseed

8 cake treatment (Table 3). Moreover, significant positive correlation was found between

9 extractable S concentration in soil and utilization (absorbance) for phenylethyl-amine in the

10 EcoPlate in sorghum with rapeseed cake application $(r=0.94$, Supplementary material,

11 Figure S1), but not in soybean. These results imply that the biochar enhanced the microbial

12 decomposition of organic matter, containing organic $S$ in this soil, resulting in superior

13 growth of the sorghum. In fact, for the rapeseed cake treatments, S concentration in the

14 leaves of sorghum significantly increased by biochar application (data not shown, Student's

$15 t$-test, $P<0.05)$. Considerable difference in soil extractable $S$ between soybean and

16 sorghum (Table 3) may imply considerable difference in the impact of plant root on

17 microbial community structure between different plant species as described later. Although

18 we cannot know exactly why significant effect of biochar application was observed only in

$19 \mathrm{~S}$ but not in $\mathrm{N}$ and $\mathrm{P}$, leaching and active absorption by root in $\mathrm{N}$ and fixation by soil in $\mathrm{P}$

20 may be involved in these different results.

21 It has also been suggested that biochar may change the soil microbial community structure

22 (Lehmann et al. 2011). In the present study, PCA of the EcoPlate data demonstrated that 
1 biochar application clearly changed the microbial community structure, particularly in

2 sorghum grown soils (Fig. 3). Correlation analysis was conducted to determine the factor(s)

3 responsible for biochar-induced changes in the microbial community structure. In the PCA,

4 the PC1 scores using the EcoPlate showed a strong negative correlation $(r=-0.89, n=16)$

5 with soil $\mathrm{pH}$ for sorghum but not for soybean (which showed a weak positive correlation, $\mathrm{r}$

$6=0.72, \mathrm{n}=16$ ) (Fig. 5). In fact, biochar application did not significantly affect soil $\mathrm{pH}$

7 under soybean but increased it under sorghum (Table 2). Although biochar is commonly

8 alkaline and has a potential to increase the soil $\mathrm{pH}$, the effect depends on the types of

9 biochar (Yang et al. 2016). Moreover, changes in soil $\mathrm{pH}$ by biochar application may also

10 be affected by microbial activities such as nitrification which produces $\mathrm{H}^{+}$(Yuan et al.

11 2011). The positive correlation between soil $\mathrm{pH}$ and $\mathrm{NH}_{4} / \mathrm{NO}_{3}$ ratio observed only in

12 sorghum grown soil (Supplementary material, Figure S2) supports the involvement of

13 nitrification in different responses of soil $\mathrm{pH}$ to biochar application between soybean and

14 sorghum. Together, some interactions between the sorghum rhizosphere and biochar may

15 affect soil $\mathrm{pH}$; this may be the primary factor altering the microbial community structure in

16 soils. Under soybean, biochar application had little effect on the profile of ammonium-

17 acetate-extractable mineral elements of the soil for both types of manure application (Fig.

18 4). For sorghum, however, biochar application altered the profile of the extractable

19 elements in the soil applied with rapeseed cake (Fig. 4). This alteration was mainly due to

20 the increase in the extractable concentrations of certain metals in soils due to biochar

21 application (Table 4). The biochar application increased soil $\mathrm{pH}$ in sorghum grown soil

22 applied with rapeseed cake (Table 3), which cannot explain the results of the extractable 
1 metals in this study because increasing the $\mathrm{pH}$ normally decreases the availability of certain

2 metal cations such as $\mathrm{Al}$ and $\mathrm{Cd}$ (von Uexküll and Mutert 1995; Xian and In Shokohifard

3 1989). In order to increase the solubility of these metal cations even at increased $\mathrm{pH}$

4 condition, some chelating compounds could be needed.

5 In contrast to the effects of biochar on soil, concentrations of these metals in the leaves of

6 sorghum grown in the soil with rapeseed cake did not change, or they tended to show a

7 decrease due to the biochar application, particularly in $\mathrm{Al}$ (Table 2). In case of $\mathrm{Al}$, it is well

8 known that organic ligands, such as organic acids can solubilize Al (Huang and Keller

9 1971) but also inactivate it for plant uptake (Ma and Hiradate 2000) in soil. Because

10 biochar application increased microbial activity in the soils applied with rapeseed cake (Fig.

11 2), it possibly enhanced organic matter decomposition in this soil, producing chelating

12 organic compounds such as organic acid that solubilized some metals but also made those

13 metals less available to sorghum roots. In fact, when analyzing the correlation between

14 extractable concentration of each of these metal elements and utilization (absorbance) for

15 each carbon source in the EcoPlate, highly significant correlation $(P<0.01)$ was found in

16 several carbon sources (4-hydroxy benzoic acid and Al/Ba; phenylethyl-amine and Zn; $\alpha-$

17 D-lactose and Zn) only in sorghum grown soil with rapeseed cake application

18 (Supplementary material, Figure S1). These carbon utilization characteristics of microbial

19 community in sorghum grown soil with rapeseed cake might be related to the production of

20 chelating compounds from soil organic matter to solubilize certain metals in soil.

21 In conclusion, biochar application can be an important agricultural practice for increasing

22 the efficiency of organic manure for crop cultivation. However, its effects differ depending 
1 on the plant species and organic manure type. These differences may be attributed to the

2 complicated interactions between the plant rhizosphere, biochar, organic manure, and soil

3 microorganisms. In order to elucidate these interactions, detailed analysis of the dynamics

4 of microorganisms and organic/inorganic substances in the rhizosphere of soils applied

5 with different types of organic manure is needed.

\section{References}

8 Chan YK, Van Zwieten L, Meszaros I, Downie A, Joseph S 2008: Using poultry litter $9 \quad$ biochars as soil amendments. Aust. J. Soil Res., 46, 437-444.

10 Diacono M, Montemurro F 2010: Long-term effects of organic amendments on soil fertility. 11 A review. Sustain. Agr. 2, 761-786. doi:10.1051/agro/2009040

12 Dikinya O, Mufwanzala N 2010: Chicken manure-enhanced soil fertility and productivity: Effects of application rates. J. Soil Sci. Environ. Manag., 1, 46-54.

14 Glaser B, Lehmann J, Zech W 2002: Ameliorating physical and chemical properties of highly weathered soils in the tropics with charcoal - a review. Biol. Fert. Soils, 35, 219-230. doi: 10.1007/s00374-002-0466-4

Haefele SM, Knoblauch C, Gummert M, Konboon Y, Koyama S 2008: Black carbon (biochar) in rice-based systems: Characteristics and opportunities. In: Woods WI, Teixeira WG, Lehmann J, Steiner C, Prins, A.W, Rebellatods L. (eds.) Amazon dark earths: Wim Soembrok’s vision, pp. 445-463. Springer, Amsterdam.

21 Hille M, Den Ouden J 2005: Charcoal and activated carbon as adsorbate of phytotoxic 22 compound: a comparative study. Oikos, 108, 202-207. 
1 Huang WH, Keller WD 1971: Dissolution of clay minerals in dilute organic acids at room

2 temperature. Am. Mineral., 56, 1082-1095.

3 Kasozi GN, Zimmerman AR, Nkedi-Kizza P, Gao B 2010: Catechol and humic acid

4 sorption onto a range of laboratory-produced black carbons (biochars). Environ. Sci.

5 Technol., 44, 6189-6195.

6 Lal R 2009: Soils and food sufficiency. A review. Agron. Sustain. Dev., 29, 113-133.

7 Lair GJ, Gerzabek MH, Haberhauer G, Jakusch M, Kirchmann H 2006: Response of the 8 sorption behavior of $\mathrm{Cu}, \mathrm{Cd}$, and $\mathrm{Zn}$ to different soil management. J. Plant Nutr. $9 \quad$ Soil Sci., 169, 60-68.

10 Lehmann J, de Silva JP Jr, Steiner C, Nehls T, Zech W, Glaser B 2003: Nutrient 11 availability and leaching in an archaeological Anthrosol and a Ferralsol of the 12 Central Amazon basin: fertilizer, manure and charcoal amendments. Plant Soil, 249, $13 \quad 343-357$.

14 Lehmann J, Joseph S 2009: Biochar for environmental management: an introduction. In: 15 Lehmann J, Joseph S (eds) Biochar for Environmental Management Science and 16 Technology, pp. 1-12. Earthscan, London, UK.

17 Lehmann J, Rillig MC, Thies J, Masiello CA, Hockaday WC, Crowley D 2011: Biochar 18 effects on soil biota - A review. Soil Biol. Biochem., 43, 1812-1836.

19 Ma JF, Hiradate S 2000: Form of aluminium for uptake and translocation in buckwheat 20 (Fagopyrum esculentum Moench). Planta, 211, 355-360.

21 Masulili A, Wani HU, Syechfani MS 2010: Rice husk biochar for rice based cropping 22 system in acid soil 1 . The characteristics of rice husk biochar and its influence on 
the properties of acid sulfate soils and rice growth in West Kalimantan, Indonesia. J. Agr. Sci., 2, 39-47.

Pietikainen J, Kiikkila O, Pritze H 2000: Charcoal as a habitat for microbe and its effects on the microbial community of the underlying humus. Oikos, 89, 231-242.

Ryan J, Sommer R, Ibrikci H 2012: Fertilizer best management practices: a perspective from the dryland West Asia-North Africa region. J. Agron. Crop Sci. 198, 57-67.

Sohi S, Lopez-Capel E, Krull E, Bol R 2009: Biochar, climate change and soil: a review to guide future research. CSIRO Land and Water Science Report 05/09 February 2009.

Tagoe SO, Takatsugu HT, Matsui T 2008: Effects of carbonized and dried chicken manures on the growth, yield, and N content of soybean. Plant Soil, 306, 211-220.

Topoliantz S, Ponge, JF, Ballof S 2007: Manioc peel and charcoal: a potential organic amendment for sustainable soil fertility in the tropics. Biol. Fert. Soils, 41, 15-21.

von Uexküll HR, Mutert E 1995: Global extent, development and economic impact of acid soils. Plant Soil, 171, 1-15.

Watanabe T, Urayama M, Shinano T, Okada R, Osaki M 2015: Application of ionomics to plant and soil in fields under long- term fertilizer trials. SpringerPlus, 4, 781. doi:10.1186/s40064-015-1562-X.

Woods J, Williams A, Hughes JK, Black M, Murphy R 2010: Energy and the food system. Philos. T. Roy. Soc. B, 365, 2991-3006.

Xian X, In Shokohifard G 1989: Effect of pH on chemical forms and plant availability of cadmium, zinc, and lead in polluted soils. Water Air Soil Poll..2 45, 265-273. doi:10.1007/bf00283457 
1 Yamato M, Okimori Y, Wibowo IF, Anshori S, Ogawa M 2006: Effects of application of

\section{Figure legends} charred bark of Acacia mangium on the yield of maize, cowpea and peanut, and soil chemical properties in South Sumatra, Indonesia. Soil Sci. Plant Nutr., 52, 489-495.

Yang X, Liu J, McGrouther K, Huang H, Lu K, Guo X, He L, Lin X, Che L, Ye Z, Wang H 2016: Effect of biochar on the extractability of heavy metals (Cd, $\mathrm{Cu}, \mathrm{Pb}$, and $\mathrm{Zn}$ ) and enzyme activity in soil. Environ. Sci. Pollut. Res. 23, 974-984.

Yuan J-H, Xu R-K, Qian W, Wang R-H 2011: Comparison of the ameliorating effects on an acidic ultisol between four crop straws and their biochars. J. Soils Sediments, 11, 741-750. doi: 10.1007/s11368-011-0365-0

Figure 1. Dry weight of soybean and sorghum. - and $\square$ indicate root and shoot, respectively. The error bars represent the standard error of the mean $(n=4) . *$ indicates a significant difference between treatments with and without biochar in each organic manure treatment (M1 or M2) $(P<0.05$, Student's $t$-test). Relative value of the B1 treatment to the B0 treatment is indicated on the bar of B1 in each manure treatment. B0: without biochar; B1: with biochar; M1: cattle farmyard manure; M2: rapeseed cake.

Figure 2. AWCD values of soybean and sorghum grown soils. Error bars represent the standard error of the mean $(n=4) . *$ indicates a significant difference between treatments with and without biochar in each organic manure treatment (M1 or 
M2) $(P<0.05$, Student's $t$-test $)$. B0: without biochar; B1: with biochar; M1: cattle farmyard manure; M2: rapeseed cake. Data recorded 144 and 120 h after the incubation started were used for soybean and sorghum, respectively.

4

5 Figure 3. Principal component analysis of carbon source utilization activity (EcoPlate) in after the incubation started were used for soybean and sorghum, respectively. soybean and sorghum grown soils. B0: without biochar; B1: with biochar; M1: cattle farmyard manure; M2: rapeseed cake. Data recorded at 144 and $120 \mathrm{~h}$

Figure 4. Principal component analysis of ammonium acetate-extractable mineral elements in soybean and sorghum grown soils. B0: without biochar; B1: with biochar; M1: cattle farmyard manure; M2: rapeseed cake.

13

14 Figure 5. Correlation of soil pH with PC1 or PC2 of PCA $(P<0.01)$ in the EcoPlate for soybean and sorghum grown soils.

16 
Table 1. Treatments in this study.

\begin{tabular}{cl}
\hline Treatment & \multicolumn{1}{c}{ Description } \\
\hline B0M1 & no biochar + cattle farmyard manure \\
B1M1 & biochar + cattle farmyard manure \\
B0M2 & no biochar + rapeseed cake \\
B1M2 & biochar + rapeseed cake \\
\hline
\end{tabular}


Table 2. Concentration (mg kg-1 dry weight) of some metal elements in plant leaf.

\begin{tabular}{|c|c|c|c|c|c|c|c|c|c|c|c|c|c|c|c|c|c|c|c|}
\hline \multirow{2}{*}{ Soybean } & \multirow[b]{2}{*}{ B0M1 } & \multicolumn{2}{|c|}{$\mathrm{Al}$} & \multicolumn{4}{|c|}{$\mathrm{Ba}$} & \multicolumn{3}{|c|}{$\mathrm{Cd}$} & \multicolumn{3}{|c|}{ Co } & \multicolumn{3}{|c|}{$\mathrm{Sr}$} & \multicolumn{3}{|c|}{$\mathrm{Zn}$} \\
\hline & & 55.33 & \pm 6.48 & C & 79.4 & \pm 5.9 & $\mathrm{a}$ & 0.261 & \pm 0.018 & $a b$ & 0.175 & \pm 0.006 & $\mathrm{~b}$ & 91.2 & \pm 5.5 & $\mathrm{a}$ & 154.0 & \pm 8.4 & $\mathrm{a}$ \\
\hline & B1M1 & 70.71 & \pm 3.55 & bc & 48.7 & \pm 5.0 & $\mathrm{~b}$ & 0.164 & \pm 0.013 & C & 0.181 & \pm 0.006 & b & 71.2 & \pm 2.6 & b & 124.7 & \pm 8.3 & b \\
\hline & B0M2 & 94.16 & \pm 4.29 & $\mathrm{a}$ & 13.3 & \pm 0.3 & C & 0.303 & \pm 0.007 & $\mathrm{a}$ & 0.223 & \pm 0.011 & $\mathrm{a}$ & 79.4 & \pm 1.7 & $a b$ & 173.9 & \pm 3.1 & $\mathrm{ab}$ \\
\hline & B1M2 & 85.61 & \pm 4.97 & $\mathrm{ab}$ & 20.2 & \pm 0.6 & C & 0.244 & \pm 0.004 & b & 0.204 & \pm 0.007 & $a b$ & 70.5 & \pm 0.7 & $\mathrm{~b}$ & 148.9 & \pm 9.5 & C \\
\hline Sorghum & B0M1 & 65.38 & \pm 7.90 & $\mathrm{~b}$ & 14.8 & \pm 0.9 & $\mathrm{a}$ & 2.11 & \pm 0.22 & bc & 0.080 & \pm 0.006 & $\mathrm{~b}$ & 24.7 & \pm 1.1 & $a b$ & 108.6 & \pm 3.9 & $\mathrm{a}$ \\
\hline & B1M1 & 40.71 & \pm 2.42 & $\mathrm{~b}$ & 14.5 & \pm 0.8 & $\mathrm{a}$ & 1.71 & \pm 0.09 & C & 0.055 & \pm 0.003 & $\mathrm{~b}$ & 22.0 & \pm 1.3 & $\mathrm{~b}$ & 79.4 & \pm 3.9 & b \\
\hline & B0M2 & 360.54 & \pm 41.32 & $\mathrm{a}$ & 8.4 & \pm 0.8 & b & 2.81 & \pm 0.13 & $\mathrm{a}$ & 0.308 & \pm 0.028 & $\mathrm{a}$ & 28.3 & \pm 0.5 & $\mathrm{a}$ & 114.3 & \pm 3.2 & $\mathrm{a}$ \\
\hline & B1M2 & 61.92 & \pm 4.77 & $\mathrm{~b}$ & 7.7 & \pm 0.4 & $\mathrm{~b}$ & 2.61 & \pm 0.07 & $\mathrm{ab}$ & 0.068 & \pm 0.004 & $\mathrm{~b}$ & 24.9 & \pm 0.7 & $\mathrm{ab}$ & 93.9 & \pm 1.9 & C \\
\hline
\end{tabular}

Different letters indicate significant difference at $P<0.05$ in each species (Tukey's multiple range test). 
Table 3. $\mathrm{pH}$ and concentration (mg kg ${ }^{-1}$ dry soil) of $\mathrm{NH}_{4}-\mathrm{N}, \mathrm{NO}_{3}-\mathrm{N}$, Truog-P, and ammonium acetate-extractable $\mathrm{S}$ in soil.

\begin{tabular}{|c|c|c|c|c|c|c|c|c|c|c|c|c|c|c|c|c|}
\hline & \multicolumn{4}{|c|}{$\mathrm{pH}$} & \multicolumn{2}{|c|}{$\mathrm{NH}_{4}-\mathrm{N}$} & \multicolumn{4}{|c|}{$\mathrm{NO}_{3}-\mathrm{N}$} & \multicolumn{3}{|c|}{$\mathrm{P}$} & \multicolumn{3}{|c|}{ S } \\
\hline \multirow[t]{4}{*}{ Soybean } & B0M1 & 5.26 & \pm 0.04 & $\mathrm{a}$ & 105.3 & \pm 20.1 & $\mathrm{a}$ & 14.9 & \pm 0.9 & $\mathrm{a}$ & 546 & \pm 17 & $\mathrm{a}$ & 91 & \pm 5 & C \\
\hline & B1M1 & 5.41 & \pm 0.06 & $\mathrm{a}$ & 85.6 & \pm 20.8 & $\mathrm{a}$ & 9.0 & \pm 2.0 & $\mathrm{~b}$ & 568 & \pm 22 & $\mathrm{a}$ & 98 & \pm 2 & C \\
\hline & B0M2 & 4.88 & \pm 0.02 & $\mathrm{~b}$ & 38.7 & \pm 10.3 & $\mathrm{a}$ & 13.3 & \pm 1.1 & $a b$ & 287 & \pm 12 & b & 362 & \pm 13 & $\mathrm{a}$ \\
\hline & B1M2 & 4.99 & \pm 0.02 & $\mathrm{~b}$ & 47.6 & \pm 8.2 & $\mathrm{a}$ & 10.4 & \pm 1.3 & $a b$ & 267 & \pm 5 & $\mathrm{~b}$ & 303 & \pm 6 & $\mathrm{~b}$ \\
\hline \multirow[t]{4}{*}{ Sorghum } & B0M1 & 5.23 & \pm 0.03 & $\mathrm{~b}$ & 38.1 & \pm 5.2 & $\mathrm{a}$ & 21.0 & \pm 1.3 & $\mathrm{ab}$ & 595 & \pm 24 & $\mathrm{a}$ & 92 & \pm 2 & $\mathrm{~b}$ \\
\hline & B1M1 & 5.47 & \pm 0.03 & $\mathrm{a}$ & 33.1 & \pm 1.7 & $\mathrm{a}$ & 12.2 & \pm 0.7 & $\mathrm{~b}$ & 601 & \pm 20 & $\mathrm{a}$ & 109 & \pm 7 & $\mathrm{~b}$ \\
\hline & B0M2 & 4.81 & \pm 0.02 & d & 22.8 & \pm 3.1 & $\mathrm{a}$ & 28.8 & \pm 3.9 & $\mathrm{a}$ & 293 & \pm 23 & b & 1506 & \pm 418 & b \\
\hline & B1M2 & 4.98 & \pm 0.01 & C & 34.9 & \pm 5.0 & $\mathrm{a}$ & 21.8 & \pm 2.4 & $\mathrm{ab}$ & 278 & \pm 9 & $\mathrm{~b}$ & 9245 & \pm 2390 & $\mathrm{a}$ \\
\hline
\end{tabular}

Different letters indicate significant difference at $P<0.05$ in each species (Tukey's multiple range test). 
Table 4. Concentration ( $\mathrm{mg} \mathrm{kg}^{-1}$ dry soil) of some metal elements in the soil extract.

\begin{tabular}{|c|c|c|c|c|c|c|c|c|c|c|c|c|c|c|c|c|c|c|c|}
\hline \multirow{2}{*}{ Soybean } & \multirow[b]{2}{*}{ B0M1 } & \multicolumn{2}{|c|}{$\mathrm{Al}$} & \multicolumn{3}{|c|}{$\mathrm{Ba}$} & & \multicolumn{2}{|c|}{$\mathrm{Cd}$} & \multicolumn{4}{|c|}{ Co } & \multicolumn{2}{|c|}{$\mathrm{Sr}$} & \multicolumn{4}{|c|}{$\mathrm{Zn}$} \\
\hline & & 5.20 & \pm 0.59 & $\mathrm{a}$ & 30.0 & \pm 1.3 & $\mathrm{~b}$ & 0.064 & \pm 0.003 & $\mathrm{~b}$ & 0.026 & \pm 0.002 & bc & 14.0 & \pm 0.6 & $\mathrm{~b}$ & 1.19 & \pm 0.29 & $\mathrm{C}$ \\
\hline & B1M1 & 4.23 & \pm 1.26 & $\mathrm{a}$ & 26.7 & \pm 1.8 & $\mathrm{~b}$ & 0.060 & \pm 0.002 & $\mathrm{~b}$ & 0.022 & \pm 0.000 & C & 14.0 & \pm 0.7 & $\mathrm{~b}$ & 3.95 & \pm 0.67 & $\mathrm{a}$ \\
\hline & B0M2 & 3.85 & \pm 0.81 & $\mathrm{a}$ & 38.3 & \pm 1.9 & $\mathrm{a}$ & 0.100 & \pm 0.006 & $\mathrm{a}$ & 0.035 & \pm 0.002 & $a b$ & 19.5 & \pm 0.9 & $\mathrm{a}$ & 1.49 & \pm 0.44 & bc \\
\hline & B1M2 & 4.11 & \pm 0.37 & $\mathrm{a}$ & 38.4 & \pm 1.5 & $\mathrm{a}$ & 0.098 & \pm 0.009 & $\mathrm{a}$ & 0.032 & \pm 0.003 & $a b$ & 19.4 & \pm 1.4 & $\mathrm{a}$ & 0.63 & \pm 0.20 & C \\
\hline Sorghum & B0M1 & 3.84 & \pm 0.47 & C & 31.6 & \pm 0.5 & $\mathrm{~b}$ & 0.084 & \pm 0.001 & C & 0.033 & \pm 0.001 & b & 17.2 & \pm 0.3 & C & 1.86 & \pm 0.47 & C \\
\hline & B1M1 & 3.96 & \pm 0.59 & C & 38.4 & \pm 3.7 & $\mathrm{~b}$ & 0.093 & \pm 0.011 & C & 0.030 & \pm 0.003 & b & 20.2 & \pm 1.8 & C & 2.16 & \pm 0.61 & C \\
\hline & B0M2 & 11.05 & \pm 1.20 & $\mathrm{~b}$ & 173.9 & \pm 41.1 & $\mathrm{~b}$ & 0.327 & \pm 0.037 & $\mathrm{~b}$ & 0.103 & \pm 0.012 & $\mathrm{a}$ & 51.0 & \pm 5.4 & $\mathrm{~b}$ & 11.47 & \pm 0.66 & b \\
\hline & B1M2 & 18.61 & \pm 1.80 & $\mathrm{a}$ & 1528.5 & \pm 403.8 & $\mathrm{a}$ & 0.543 & \pm 0.066 & $\mathrm{a}$ & 0.127 & \pm 0.014 & $\mathrm{a}$ & 83.7 & \pm 9.9 & $\mathrm{a}$ & 17.51 & \pm 1.68 & $\mathrm{a}$ \\
\hline
\end{tabular}

Different letters indicate significant difference at $P<0.05$ in each species (Tukey's multiple range test). 
Soybean

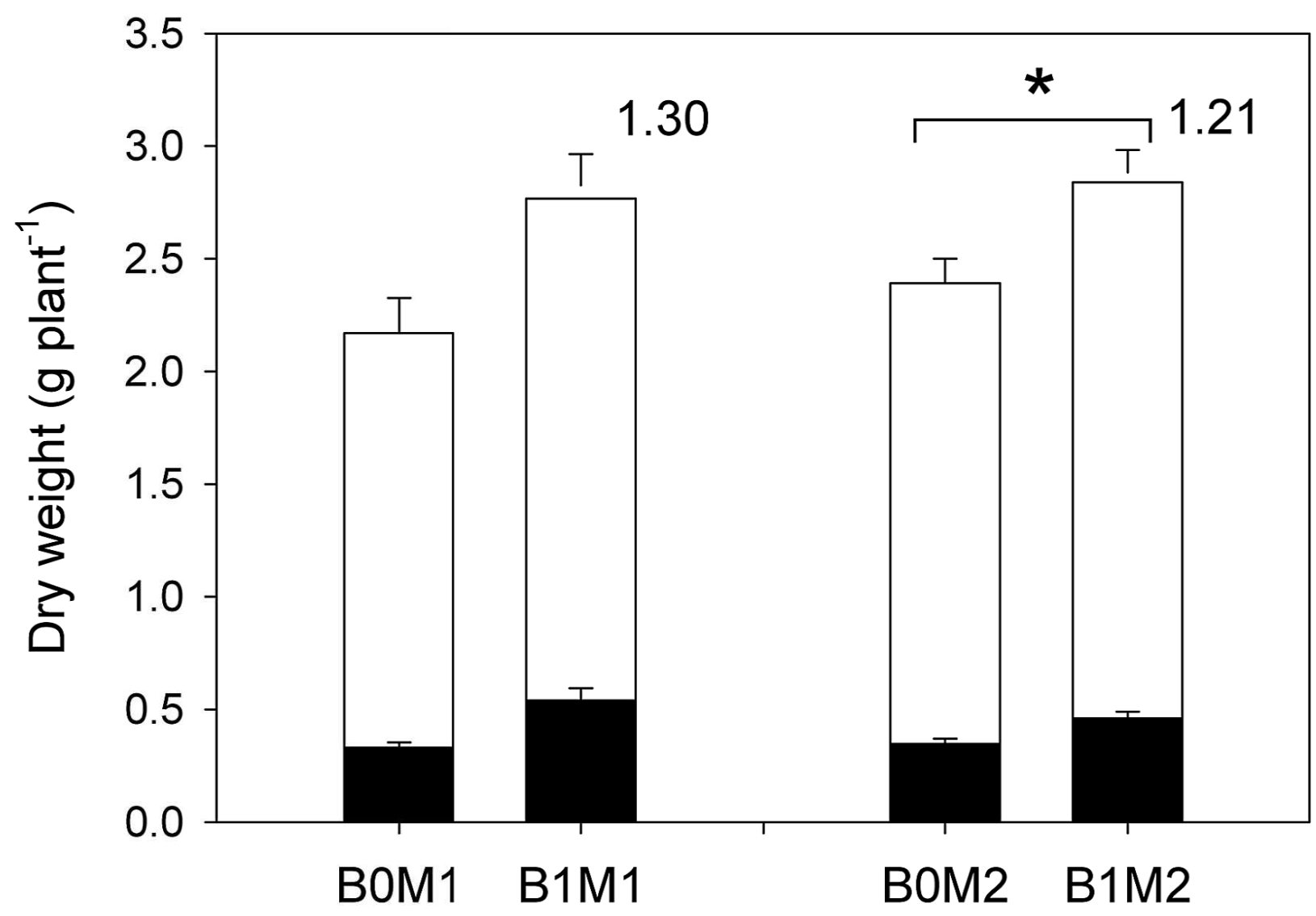

Sorghum

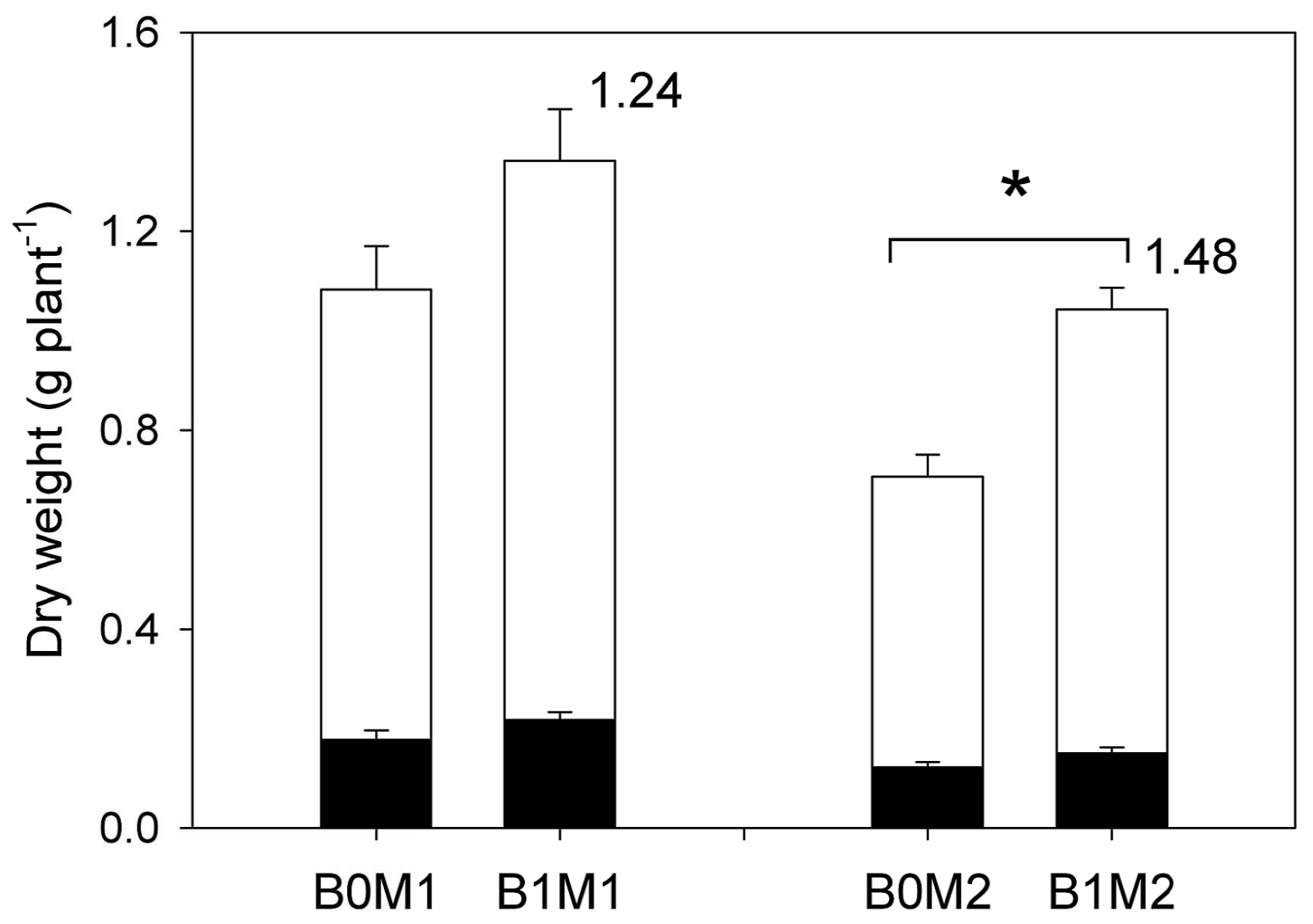


Soybean

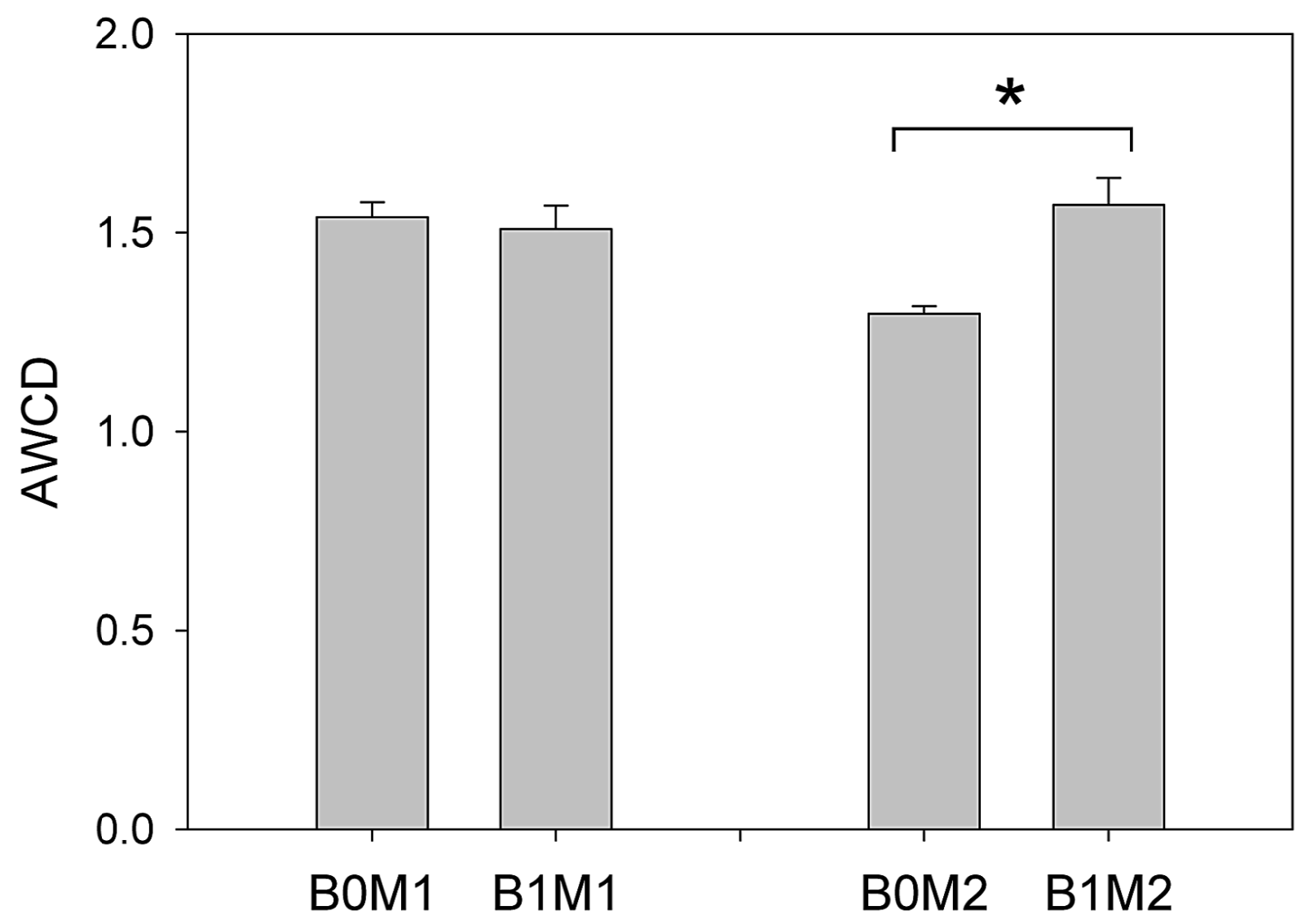

Sorghum

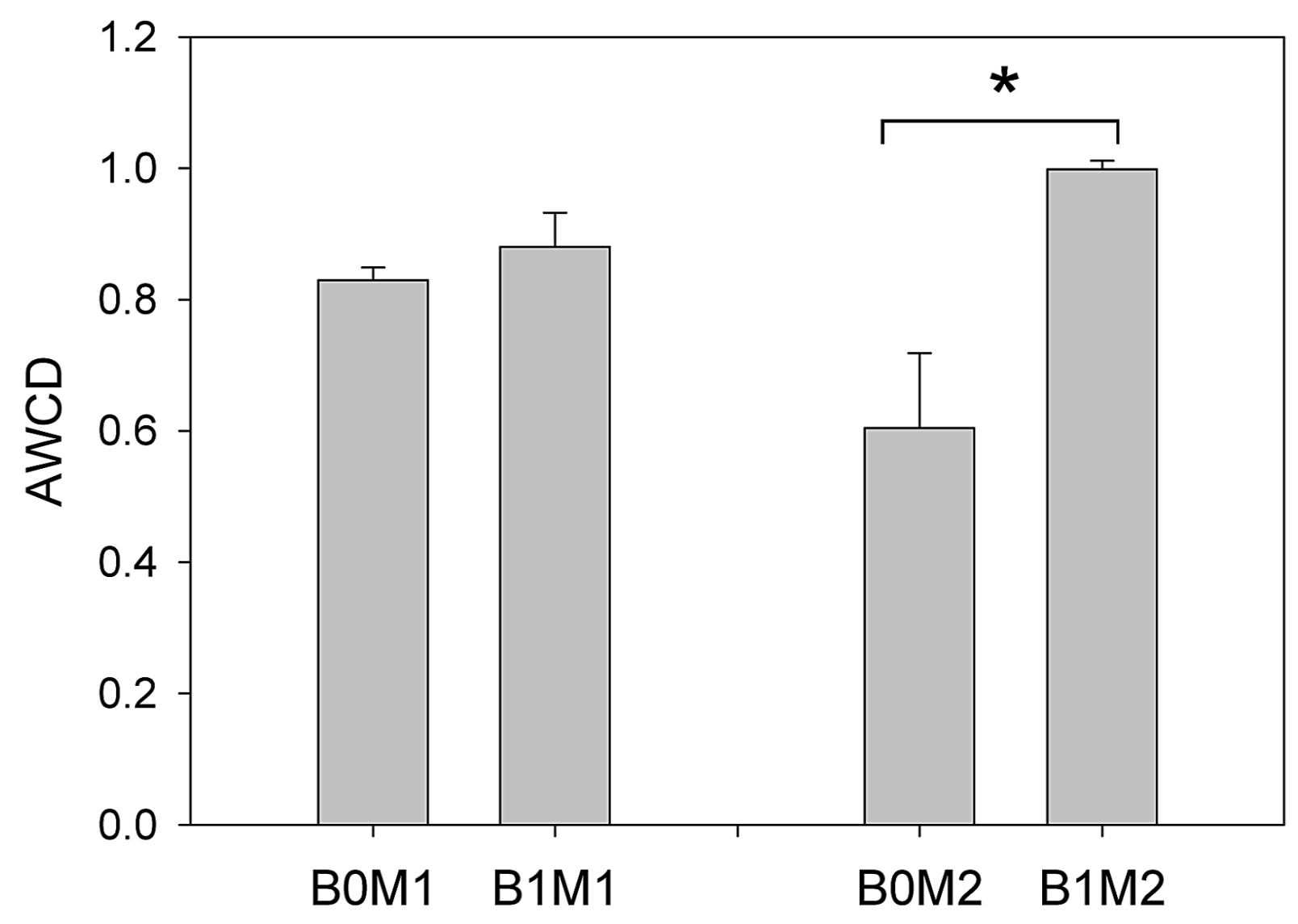


Soybean

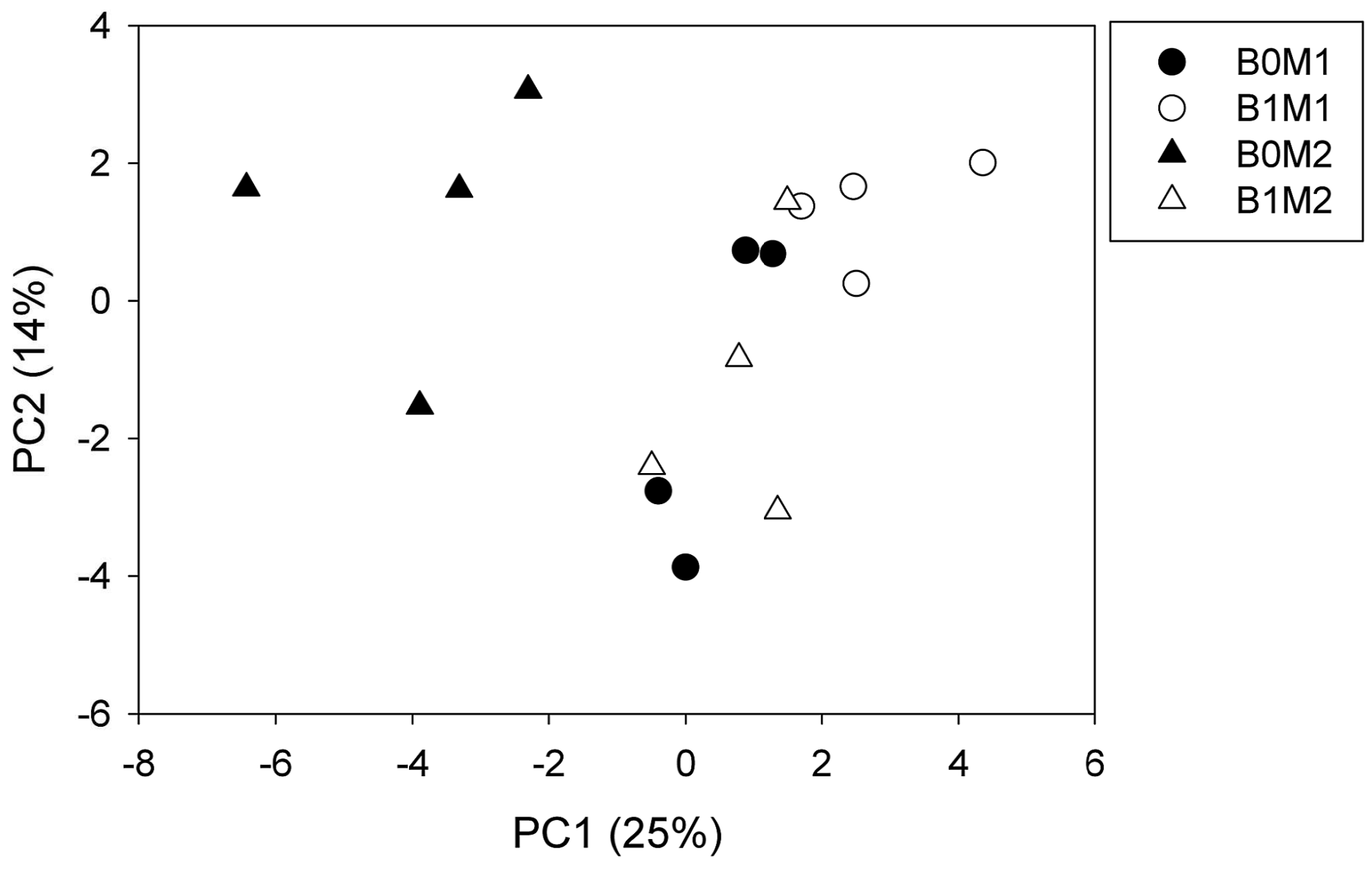

Sorghum

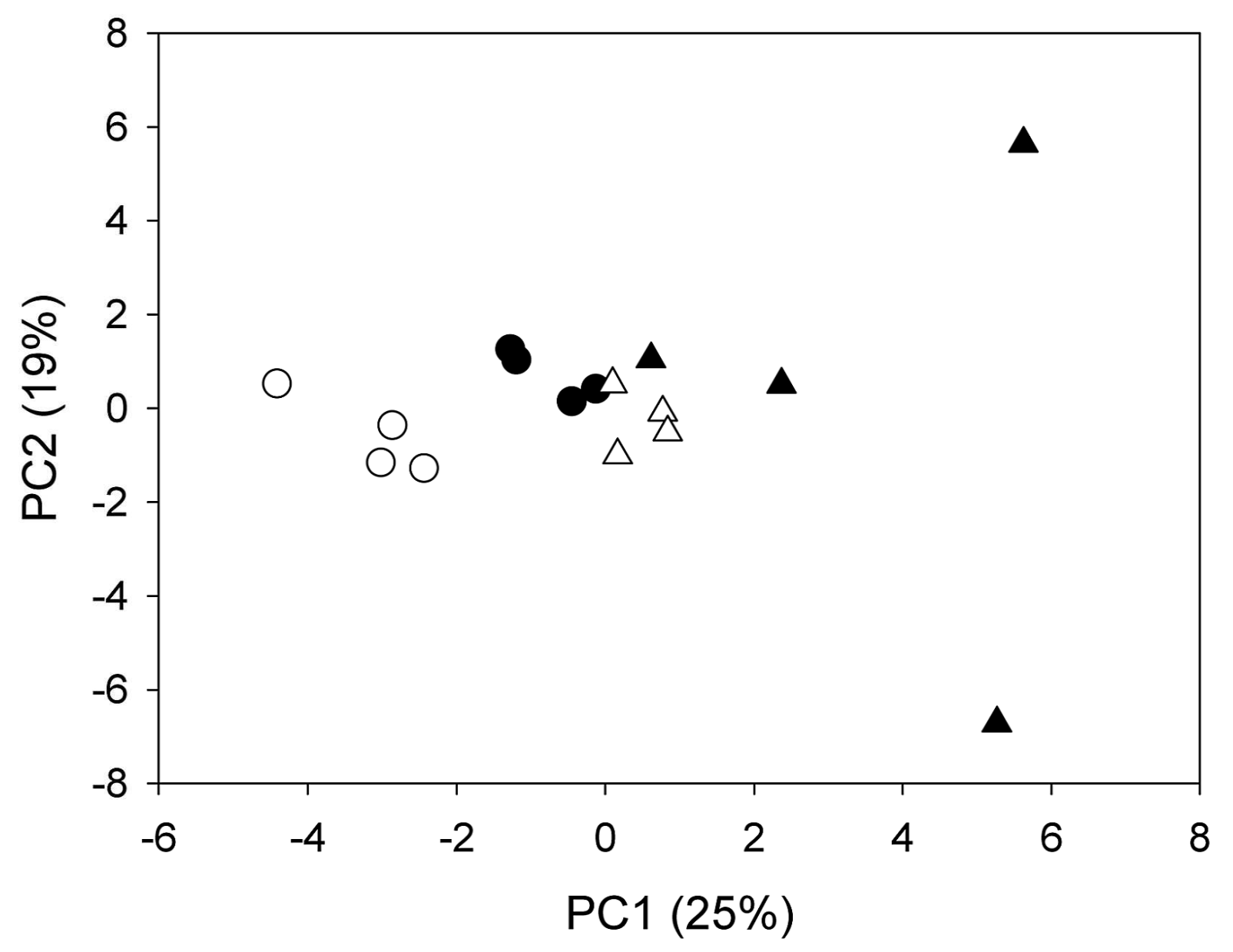


Soybean

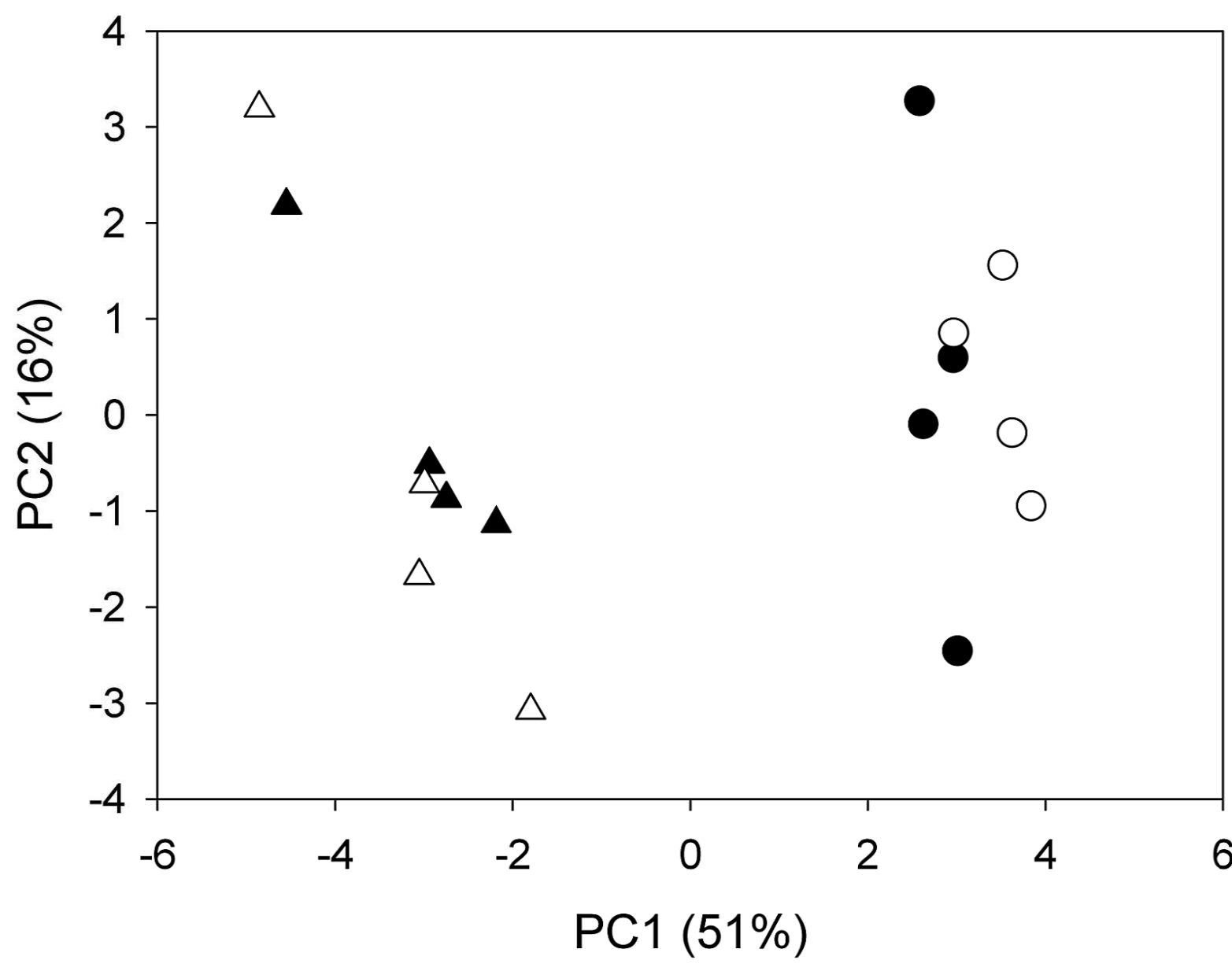

Sorghum

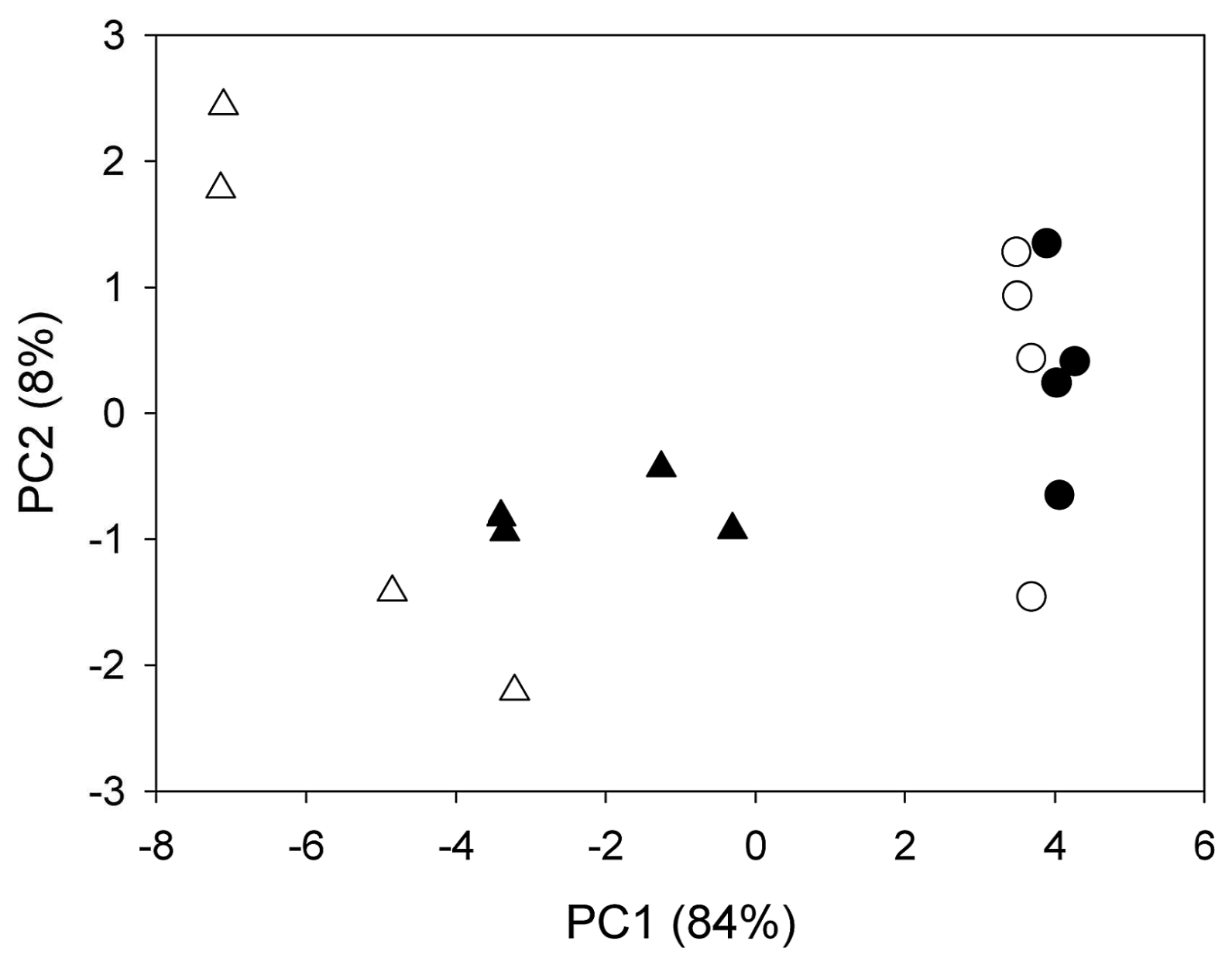


Soybean
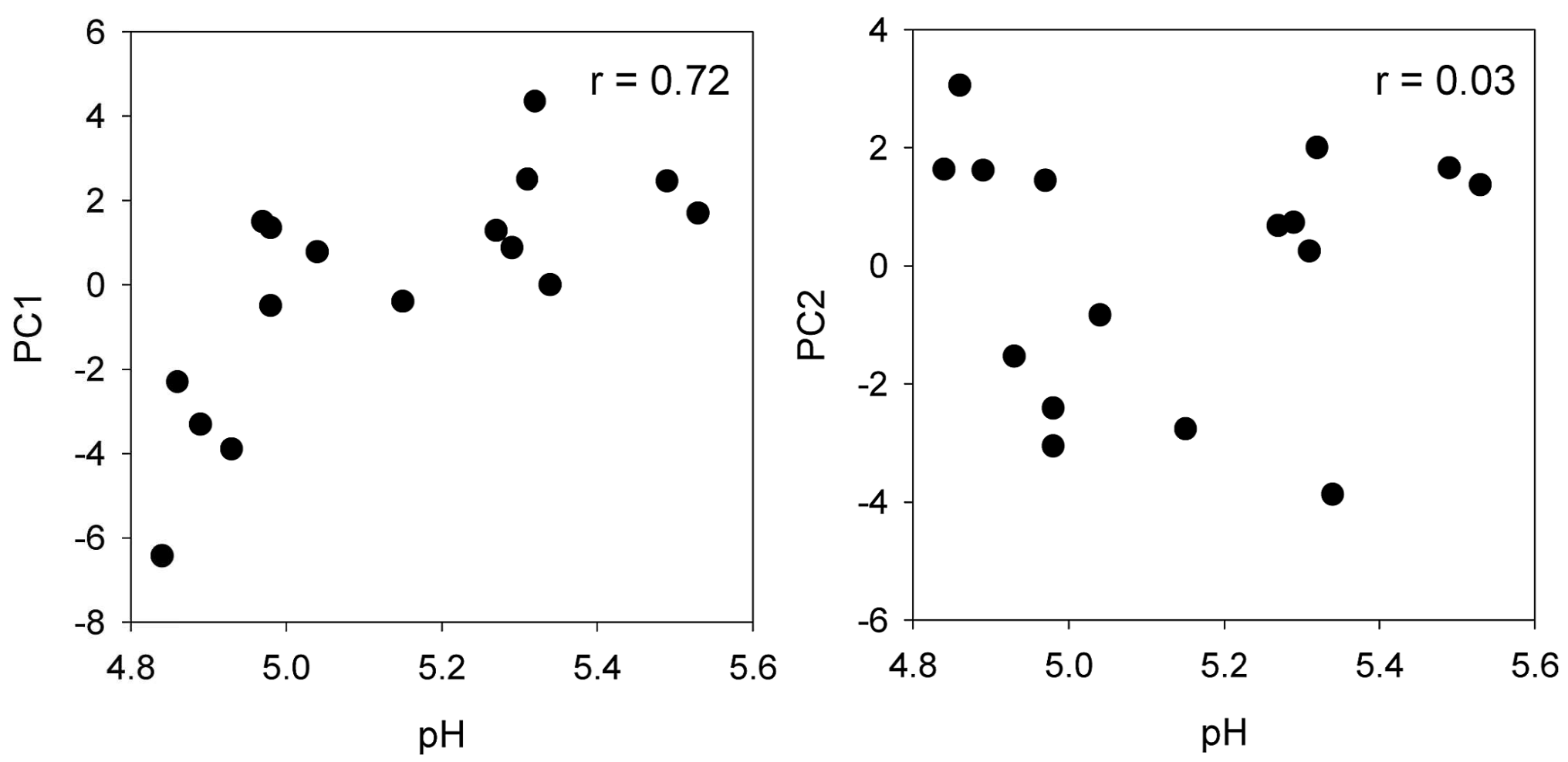

Sorghum
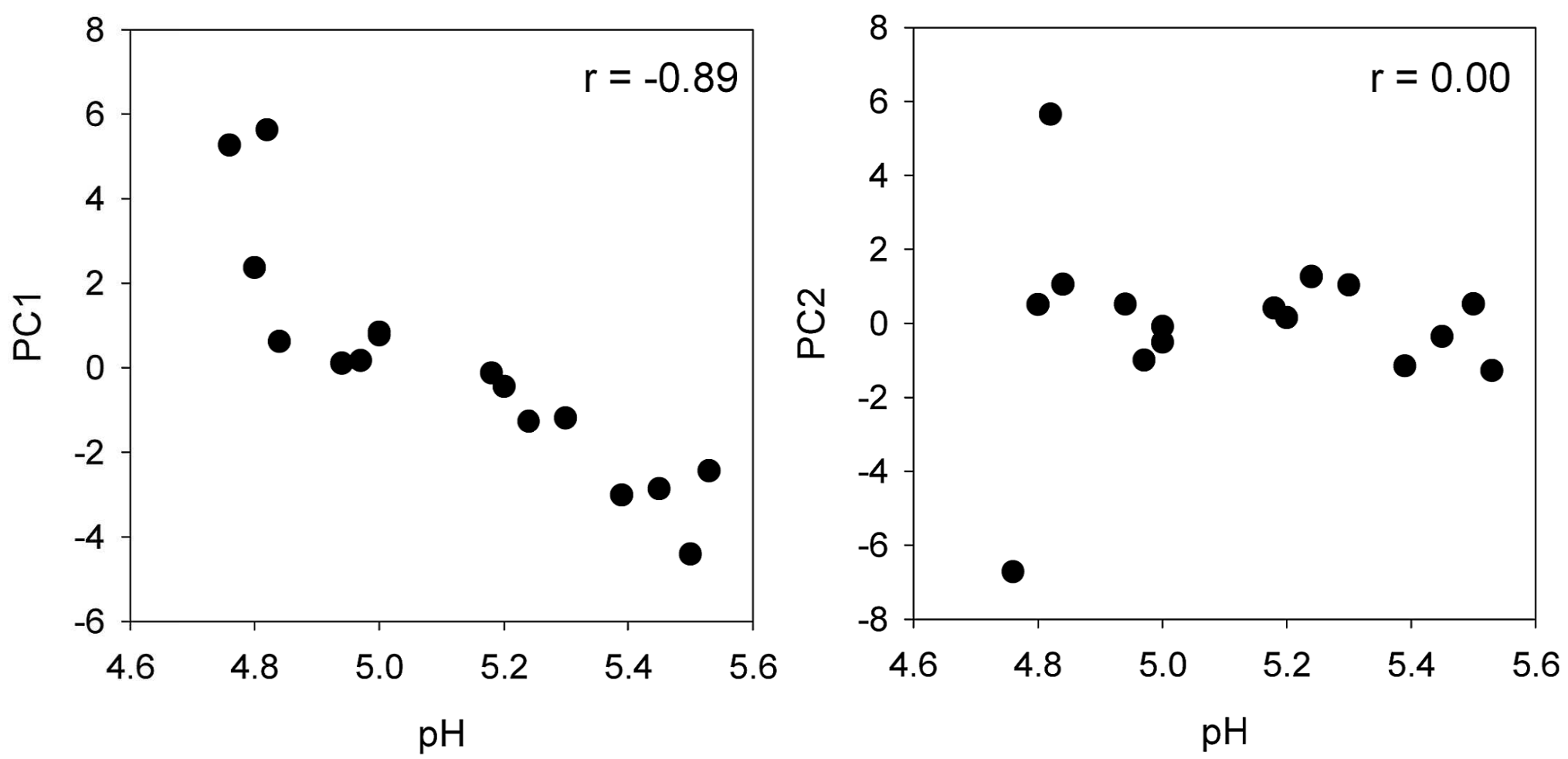

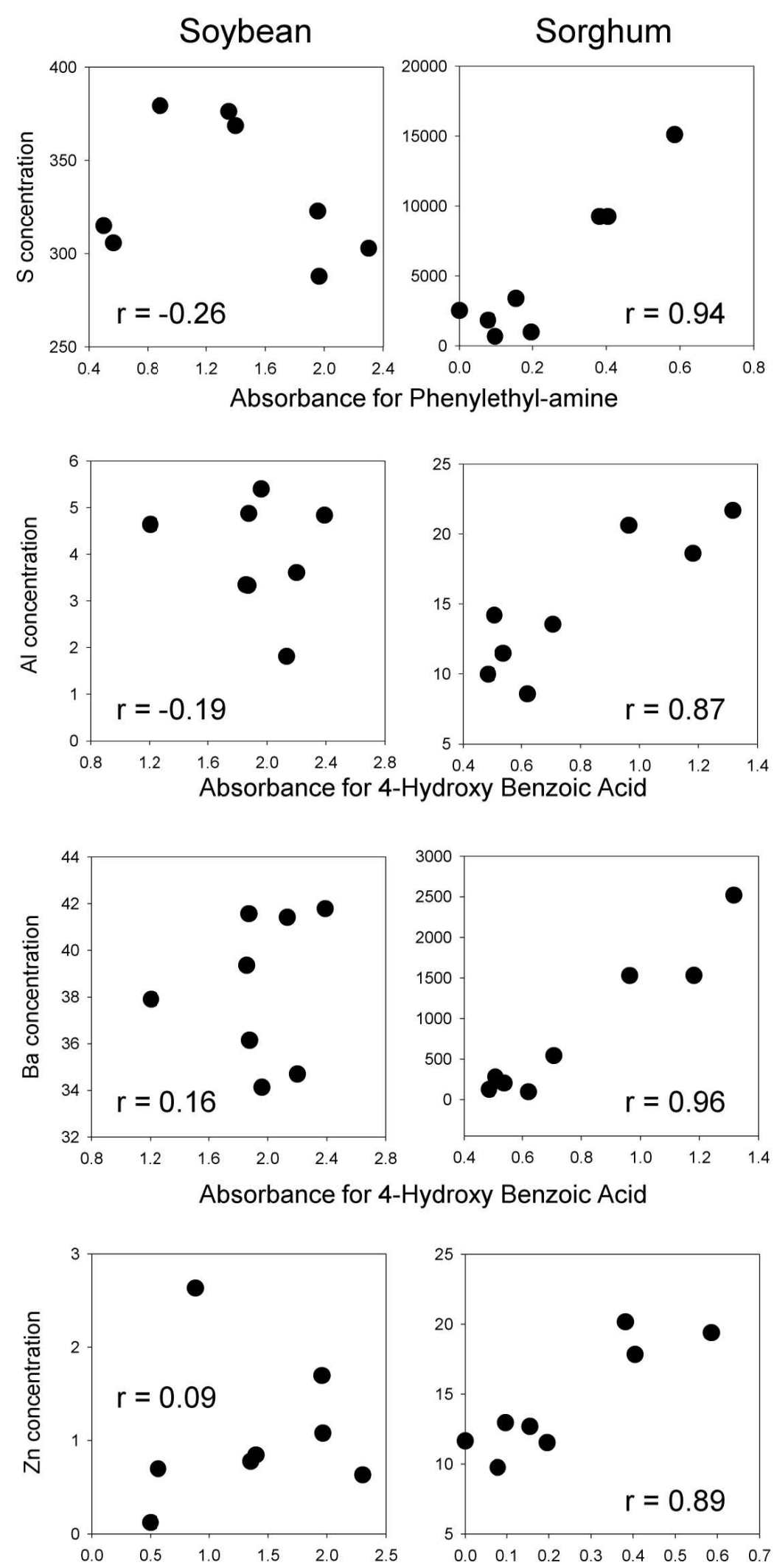

Absorbance for Phenylethyl-amine
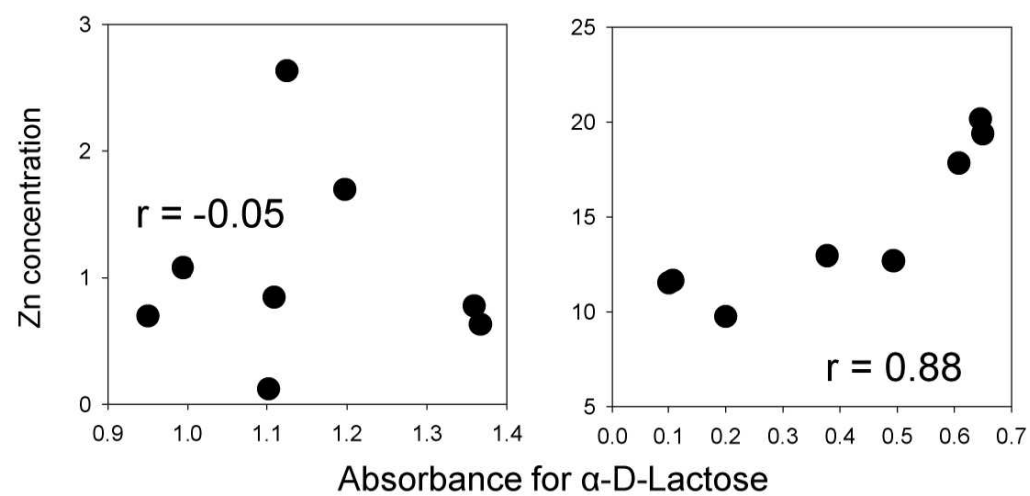

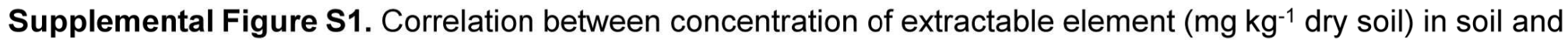
utilization (absorbance in Biolog Ecoplate) of carbon source in microbial community of soil with rapeseed cake (including both with and without biochar). Only pairs with significant positive correlation $(P<0.01)$ were shown. 
Soybean

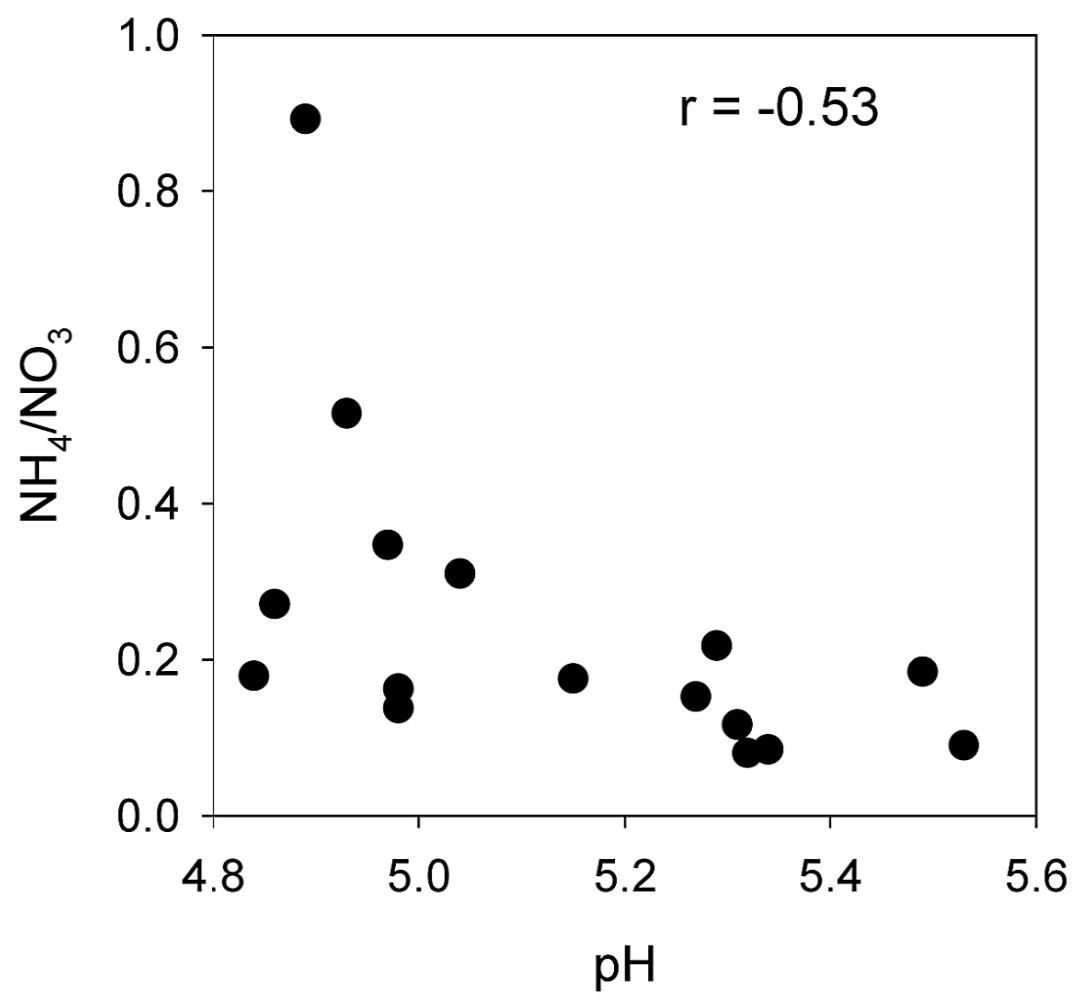

Sorghum

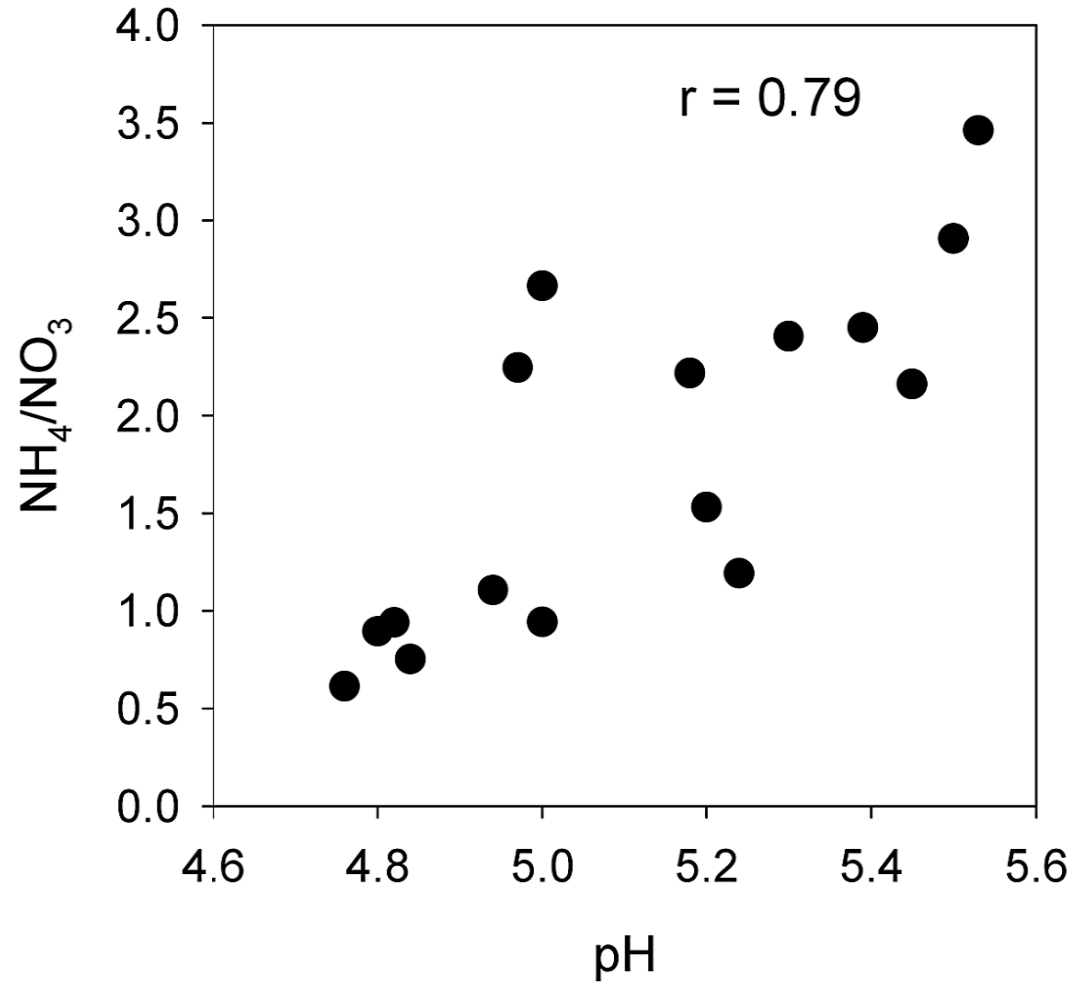

Supplemental Figure S2. Correlation between $\mathrm{pH}$ and $\mathrm{NH}_{4} / \mathrm{NO}_{3}$ ratio in soils. 